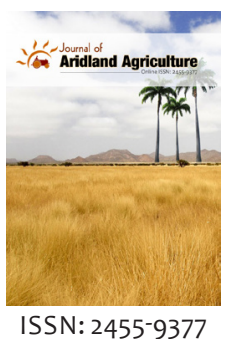

ISSN: $2455-9377$

Received: July 10, 2020

Revised: February 22, 2021

Accepted: February 24, 2021

Published: March 11, 2021

*Corresponding Author:

Riyad Hossen,

E-mail: rhossen@bu.ac.bd

\section{Onion cultivation approach by custom-made outdoor hydroponics: A very first attempt in Bangladesh}

\author{
Irani Khatun, Saydul Karim, Subroto K Das, Riyad Hossen* \\ Department of Botany, University of Barishal, Barishal-8254, Bangladesh
}

\begin{abstract}
Onion is one of the most important economic crops in the world. Since it was reported that the natural water sources of Barishal have many growth nutrients for plants, this experiment grown onions in custom-made outdoor hydroponics using ground water of Barishal (mostly from tab water) and Kirtankhola River water to check their nutrients performances for yielding purposes. Ground water demonstrated best performances and the average yields of onions in ground water were more than half of land based yields comparatively. Besides, plant growth was normal in ground water throughout the experiment. The results indicated that the water although is not sufficient enough without adding nutrients to produce onion commercially, but it could support the growth at a certain level.. Finally, the authors concluded onion production is possible hydroponically in Bangladesh and to minimize the load of commercial fertilizers the ground water of Barishal, as main water supply to the hydroponic units, is recommended.
\end{abstract}

KEY WORDS: Custom-made hydroponics, Outdoor hydroponics, Barishal, Onion cultivation

\section{INTRODUCTION}

Onion (Allium cepa L.) is one of the most important economic crops in the world for growing, trading and consuming. It has high amount of carbohydrates, calcium, phosphorus, vitamins, and volatile substances. Moreover, it has antibacterial and anti-fungal properties as well acted as remedy of coughs, asthma, bronchitis, blood pressure. It can prevent cancer cell growth, heart attacks or strokes (Doijode, 2001; Sampath et al., 2010). In Bangladesh, population is increasing rapidly; thus cultivating land area is diminishing due to new urbanization and industrialization. As a result, feeding a huge number of populations would be challenging in future. To face the upcoming problems, hydroponics would be a new sensation in this country to produce food in soilless medium to reduce pressure on cultivating lands. Generally, hydroponics is installed in indoor controlled environment which is costly but there have many earlier reports about successful outdoor environment hydroponic set up for crops and vegetables production (Hochmuth \& Tim, 1997; Benton, 2014). Besides, hydroponics is not quite popular for onion cultivation yet. In Bangladesh, the average production of onion is very low compared to other developing countries (Bangladesh Bureau of Statistics, 2015). This is because the scarcity of cultivating onion farmland area. The most of the farmlands are being used for rice cultivation (Mainuddin et al., 2011), although the environment of this country is also favorable for onion cultivation.
Water is at the base of food production system in Bangladesh. In Barishal district of Bangladesh, the main two freshwater sources are ground water and Kirtankhola River. Moreover, scientists assessed the compositions of these two water bodies and concluded with the presence of growth nutrients and other elements (Goswami et al., 2017; Rajonee, 2018). The growth of onion is linked with high level of NPK nutrients uptake (Nasreen, 2007) and the two water bodies were suggested to use in hydroponics for onion cultivation (Khatun et al., 2019). Hence, the research aimed to use these waters in custom-made outdoor hydroponics directly without adding any nutrients solutions to assess their performances on onions growth for future commercial purposes. Therefore, we hope that the findings will show the way of alternative onion farming techniques in Bangladesh.

\section{MATERIALS AND METHODS}

\section{Plant Material, Water Sources and Timing}

This experiment used Taherpuri variety of onion as model species. As water supply, nutrients containing ground water of Barishal (GWB) (collected through tab water), Kirtankhola River water (KRW) and nutrients less deionized water (DIW) were used. DIW was used to compare the nutrients performances of GWB and KRW. 20 days seedlings were transplanted to this experiment at $1^{\text {st }}$ week of December 2019. 
After 60 days of transplantation, mature onions were harvested before tops started falling over.

\section{Hydroponics Installation}

Custom-made hydroponic units were installed by plastic tanks $(80 \times 60 \times 40 \mathrm{~cm})$ as main containers, polystyrene foam boards $(75 \times 25 \mathrm{~cm})$ as floating trays on top of the containers, plastic cups as seedling holders and water input-outlet pipes. The seedlings were transplanted to the holders and supported by few inert types of gravels. Each tray contained 10 holders for 10 seedlings designed by same size and gap. A hand propelled mixture wheal was attached for ensuring nutrients homogeneity throughout the unit (Figure 1). Then the units were placed to the University Net House in natural light environment. The average temperature and relative humidity was 20 to $26^{\circ} \mathrm{C}$ and 65 to $52 \%$, respectively during these 60 days.

\section{Water Management}

The experimenting ground water, Kirtankhola River water and deionized water were supplied to the three units separately. To avoid other nutrients interaction in the results of the presents nutrients and elements of these waters, we did not use any hydroponic nutrients solution. After every 10 days, the waters had been changed from containers to avoid nutrient toxicity or scarcity. And regular irrigation was done to maintain fixed root-water level all time. All management procedures were performed equally for three waters.

\section{Data Collection}

Total biomass (root, leaf, and bulb weight) was calculated as fresh weight. Bulb diameter was measured by $\mathrm{cm}$ scale and chlorophyll content was determined following the protocols described by Thimmaiah (2004). Diseases and other growth disorders were recorded by field observations by the authors.

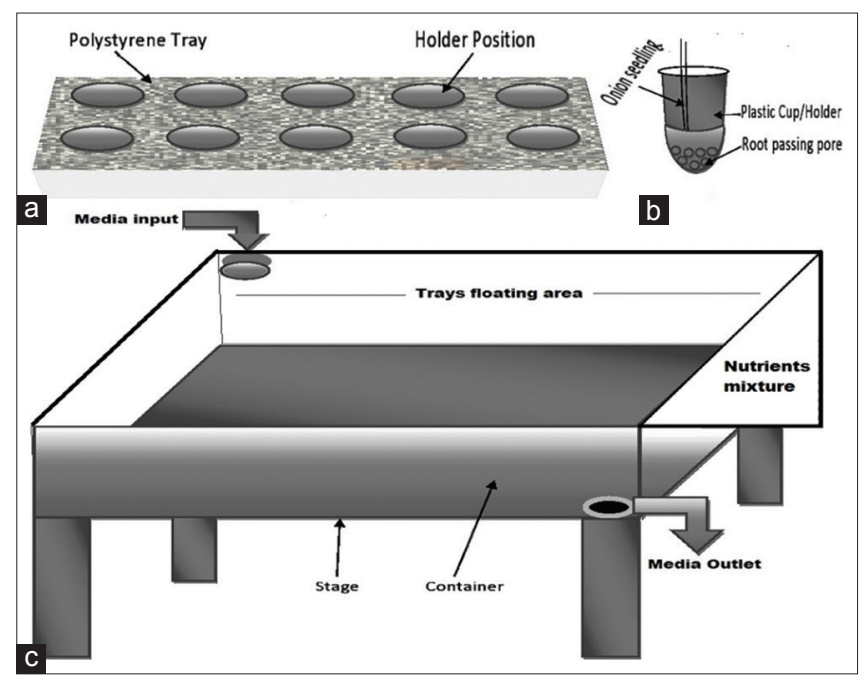

Figure 1: Diagrammatic presentation of custom-made hydroponic units. a. Polystyrene floating tray, b. Seedling holder, c. Main container unit with water input and outlet pipelines

\section{Statistical Analysis}

The outdoor hydroponic units were placed followed by randomized block design, and the experiment was performed by four replications. All obtained data were subjected to analysis of variance according to Snedecor and Cochran, and analysis was carried out using JMP computer software package (Snedecor \& Cochran, 1980). The treatment means were compared by the Least Significant Difference (LSD) test at 5\% level.

\section{RESULTS AND DISCUSSION}

In this experiment, three different types of water were used in custom-made outdoor hydroponics to grow onion. Among these, ground water of Barishal (GWB) and Kirtankhola River (KRW) water were used to check their performances on onions growth, while deionized water (DIW) was used only as nutrients zero standard water for better understanding and comparing the nutrients level's effectiveness. Our experimentation time was selected followed by onion growing season in Bangladesh because we used outdoor hydroponics, where naturally growing season is the key requirements.

Among the water sources, DIW failed to support onions growth throughout the research. The first 6 to 8 days, the seedlings were alive and leaves started to spread and after 2 weeks all were died gradually in DIW treated units. It means the DIW did not contain any growth nutrients or they had negligible amounts of nutrients, because plant development is totally dependent on growth nutrients (Marschner, 1986; Mengel \& Kirkby, 1987). On the other hand, GWB demonstrated far better results than KRW in all aspects of growth parameters. For example, the average height of plant was $33 \mathrm{~cm}$ in GWB while it was $21 \mathrm{~cm}$ in KWR treated units. Moreover, the number of leaf and the number of root grown in per plant was also higher in GWB treatments. The average leaf weight per plant and total chlorophyll content per gram of leaf was $9.25 \mathrm{~g}$ and $1.05 \mathrm{mg} / \mathrm{g}$ respectively in GWB, whereas it was $6.55 \mathrm{~g}$ and $0.90 \mathrm{mg} / \mathrm{g}$ in KRW which means the leaves were comparatively more developed by GWB treatments. Moreover, the average bulb weight was $17.20 \mathrm{~g}$ and the diameter was $2.25 \mathrm{~cm}$ in GWB, which was higher than KRW and the differences were significant statistically (Table 1). No growth related disorders were observable during these 60 days in GWB but the growth was stunting by KRW. Therefore, it indicated that the nutrients and elements present in GWB gave far better results than KRW in terms of onion growth in custom-made outdoor hydroponics.

As the GWB gave distinct outcomes than KRW, its results were compared with the results of land based production reports of the same variety of onion from Bangladesh (Sikder et al., 2010; Ali et al., 2015). Besides, the reported data were arranged as highest and lowest values since different agronomic practices following same research methodologies. The average lowest height of onion plants in outdoor hydroponics using GWB was $30 \mathrm{~cm}$ and highest was $37 \mathrm{~cm}$, while it was found 40 and 52 $\mathrm{cm}$, respectively in land based farming. Comparing the onions yields like as bulb weight and diameter, it was more than half 
Table 1: Comparison of average statistical data of onions growth in custom-made outdoor hydroponics using three supplied waters

\begin{tabular}{lcccccccc}
\hline Parameter & $\begin{array}{c}\text { Plant } \\
\text { Weight }(\mathrm{cm})\end{array}$ & $\begin{array}{c}\text { No.of leaf } \\
\text { (per plant) }\end{array}$ & $\begin{array}{c}\text { Leaf weight } \\
\text { (g) (per plant) }\end{array}$ & $\begin{array}{c}\text { No. of root } \\
\text { (per plant) }\end{array}$ & $\begin{array}{c}\text { Bulb } \\
\text { weight (g) }\end{array}$ & $\begin{array}{c}\text { Bulb } \\
\text { Diameter (cm) }\end{array}$ & $\begin{array}{c}\text { Total chlorophyll } \\
\text { content (mg/g) }\end{array}$ \\
\hline GWB & 33 & 9 & 9.25 & 30 & $17.20^{* *}$ & $2.25^{*}$ & 1.05 & Not found \\
KRW & 21 & 6 & 6.55 & 21 & 12.15 & 1.50 & 0.90 & Stunting \\
DW & ND & ND & ND & ND & ND & ND & - & Death \\
\hline
\end{tabular}

N.B. ND $=$ No Development. **means highly significant and *means significant in $\mathrm{P}=0.05$ Probability level

Table 2: Comparison of onions growth in custom-made outdoor hydroponics using GWB with land based agronomic production Data were presented in a lowest and highest range

\begin{tabular}{|c|c|c|c|c|c|c|c|}
\hline $\begin{array}{r}\text { Parameter } \\
\text { Water Source }\end{array}$ & $\begin{array}{c}\text { Plant } \\
\text { height }(\mathrm{cm})\end{array}$ & $\begin{array}{l}\text { No. of leaf } \\
\text { (per plant) }\end{array}$ & $\begin{array}{l}\text { Leaf weight } \\
\text { (per plant) }\end{array}$ & $\begin{array}{l}\text { No. of root } \\
\text { (per plant) }\end{array}$ & $\begin{array}{c}\text { Bulb } \\
\text { weight (g) }\end{array}$ & $\begin{array}{c}\text { Bulb } \\
\text { Diameter }(\mathrm{cm})\end{array}$ & Growth Disorders \\
\hline$\overline{\text { GWB }}$ & $30-37$ & $6-11$ & $7-9.25$ & $22-30$ & $13.5-16.2$ & $2-2.50$ & Not found \\
\hline Land & $40-52$ & $12-24$ & $11-14.70$ & $40-43$ & $22.6-38.9$ & $3.3-4.6$ & No report \\
\hline
\end{tabular}

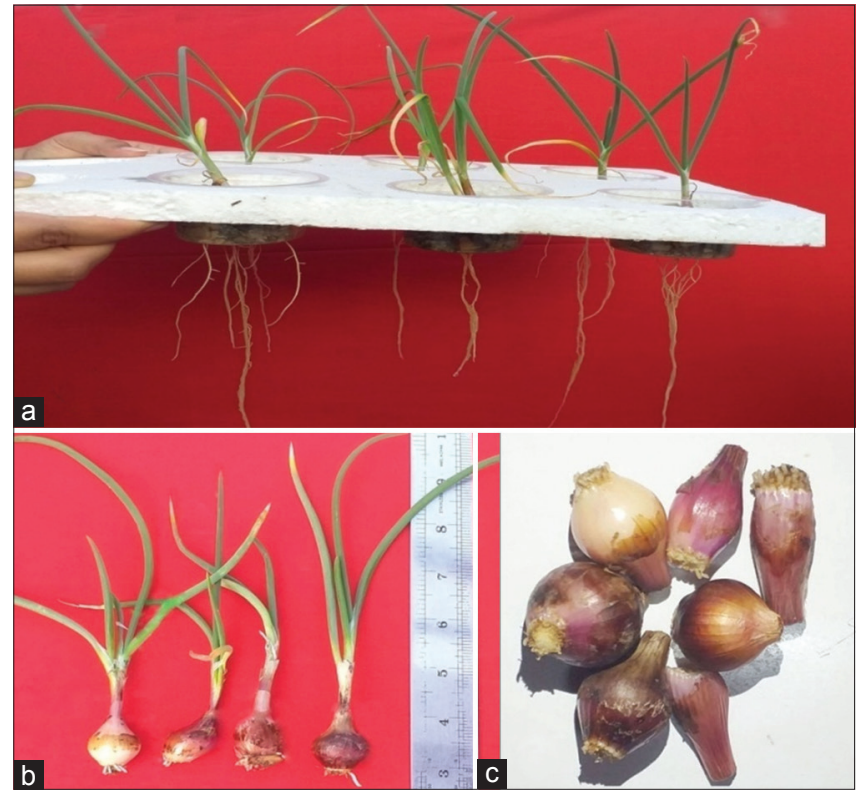

Figure 2: Hydroponically produced onions using ground water of Barishal. a. Onions in trays, b. Morphology of leaves and bulbs, c. Harvested bulbs

of land based yields in GWB and the other growth parameters also gave lower results in the hydroponics (Table 2). The earlier reports did not mention any diseases, spots or growth related abnormalities, as it was found same in outdoor hydroponics in case of GWB treatments. The experiment also had been observed almost homogenous growth in the units supplying GWB, which matched with other hydroponics principles (Hochmuth \& Tim, 1997; Benton, 2014), although it was not exact homogenous due to its outdoor environments. Moreover, roots color, length and branching pattern were almost same in GWB treated units (Figure 2a). Even the color and shape of leaves and bulbs were normal in ground water treatments (Figure $2 \mathrm{~b}$ and 2c).

From these results, it was clear that the growth and yields of onion in outdoor hydroponics supplying the GWB was lower than the land based farming but significantly higher than KRW. And, the overall homogenous growth meant that the nutrients and elements in GWB were presence in balanced ratio, and lower yields meant the only mineral nutrients present in the water were insufficient to support the heavy nutrients eater onions to reach the same level of reported yields. Furthermore, more than the half of land based onion farming yields indicated that the GWB contained a significant amount of nutrients needed for onion growth, whereas the normal growth indicated the absence of harmful elements to prevent or resist the onions growth in the outdoor hydroponics.

\section{CONCLUSION}

Finally, the authors concluded that it is possible to produce onion in outdoor hydroponics using the ground water which is able to minimize the need of nutrients solutions. The authors also suggested that to produce onion commercially in outdoor hydroponics in Bangladesh, it is mandatory to enrich the nutrients availability by adding commercial or other cheap nutrients sources.

\section{ACKNOWLEDGEMENT}

The research was carried by the financial support from the Ministry of Science and Technology of Bangladesh. The authors also wish to thank the Department of Botany, University of Barishal, Bangladesh for financial supports in part of the works.

\section{REFERENCES}

Ali, M. A., Hossain, M., Zakaria, M., Naznin, A., \& Islam, M. M. (2015) Effect of bulb size on quality seed production of onion in Bangladesh. International Journal of Agronomy and Agricultural Research, 6, 174-180.

Bangladesh Bureau of Statistics. (2015). Handbook of agricultural statistics, Annual Report 2014

Benton, J. (2014). Complete guide for growing plants hydroponically. CRC Press.

Doijode, S. D. (2001). Seed storage of horticultural crops (1 ${ }^{\text {st }}$ Eds.). New York, Haworth Press Inc.

Goswami, S., Rahman, A. K. M. M., Fuad, M. I. M., Roy, D. K., \& Rahim, A. (2017). Groundwater quality assessment of Barisal City Corporation in Bangladesh. Barisal University Journal, 4, 339-350.

Hochmuth, R., \& Tim, C. (1997). Producing strawberries in North Florida using an outdoor hydroponic system 97-6. Institute of Food and Agricultural Sciences.

Khatun, I., Das, S.K., \& Hossen, R. (2019). Assessment of germination and feasibility of hydroponic growth of onion by four common water 
sources from Barishal region, Bangladesh. Farming and Management, 4(2), 82-86. https://doi.org/10.31830/2456-8724.2019.008

Mainuddin, K., Rahman, A., Islam, N. \& Quasem, S. (2011). Planning and costing agriculture's adaptation to climate change in the salinityprone cropping system of Bangladesh. International Institute for Environment and Development (IIED), London, UK.

Marschner, H. (1986). Functions of mineral nutrients: micronutrients. In H. Marschner (Eds.), Mineral nutrition of higher plants (pp 269-340), London: Academic Press.

Mengel, K., \& Kirkby, E. A. (1987). Nutrition and plant growth. In K. Mengel \& E. A. Kirkby, Principles of plant nutrition (4th Edn, pp 247-302), Bern: International Potash Institute.

Nasreen, S., Haque, M. M., Hossain, M. A., \& Farid, A. T. M. (2007). Nutrient uptake and yield of onion as influenced by nitrogen and sulphur fertilization. Bangladesh Journal of Agricultural Research, 32, 413-420.

Rajonee, A. A. 2018. Surface water quality status around Barishal City in two different season. Bangladesh Journal of Soil Science, 40, 1-14.

Sampath, K., Debjit, B., Chiranjib, B. \& Pankaj, T. (2010). Allium cepa: A traditional medicinal herb and its health benefits. Journal of Chemical and Pharmaceutical Research, 2, 283-291.

Sikder, M. F., Mondal, D., Mohammed, M. S. \& Amin, M. B., (2010). Effect of spacing and depth of planting on growth and yield of onion. Journal of Agroforestry and Environment, 4, 105-108.

Snedecor, G., \& Cochran, W. (1980). Statistical methods (12 ${ }^{\text {th }}$ Eds.), lowa, USA: lowa State University Press.

Thimmaiah, S. R., (2004). Standard methods of biochemical analysis (1 ${ }^{\text {st }}$ Eds.), New Delhi: Kalyani Publishers. 